\title{
ANALISIS PEMANFAATAN MODUL SUPERVISI AKADEMIK DALAM MENINGKATKAN KOMPETENSI SUPERVISI PADA DIKLAT CALON KEPALA SEKOLAH
}

\author{
1) Indah Mustika Rini, \\ 2) Cepi Riyana \\ Pengembangan Kurikulum Program Pascasarjana UPI, Bandung \\ e-mail: indahrini2180@gmail.com \\ cepi@upi.edu
}

\begin{abstract}
Abstrak: Penelitian ini dilatarbelakangi oleh rendahnya kompetensi supervisi kepala sekolah berdasarkan hasil Uji Kompetensi Kepala Sekolah (UKKS) tahun 2015. Untuk meningkatkan kompetensi tersebut maka diperlukan berbagai upaya strategis melalui pendidikan dan pelatihan. Lembaga Pengembangan dan Pemberdayaan Kepala Sekolah (LPPKS) telah menyelenggarakan program diklat calon kepala sekolah sejak tahun 2010. Pelaksanaan diklat tidak terlepas dari keberadaan modul sebagai instrumental input dari sistem pembelajaran. Namun, apakah modul diklat tersebut dapat memberikan manfaat dalam meningkatkan kompetensi peserta diklat? Tujuan penelitian ini adalah untuk menganalisis dan mendeskripsikan sejauh mana pemanfaatan modul supervisi akademik dalam meningkatkan kompetensi supervisi pada diklat calon kepala sekolah. Metode pada penelitian ini deskriptif dengan pendekatan kualitatif. Teknik pengumpulan data dengan cara studi dokumen, wawancara, dan observasi. Hasil penelitian menunjukkan bahwa modul Supervisi Akademik dikembangkan dengan cara mengkompilasi dan menulis sendiri oleh tim gabungan yaitu unsur akademisi dan praktisi. Teknik layout pada modul menggunakan standar pada umumnya karya tulis ilmiah. Modul digunakan sebagai bahan pembelajaran utama. Master Trainer, sebelum melaksanakan diklat mempersiapkan skenario pembelajaran berupa RBPMD (Rancang Bangun Program Mata Diklat) dan RP (Rencana Pembelajaran) dengan alokasi waktu sebanyak 9 JP (jam pelajaran). Modul digunakan mulai dari persiapan, pelaksanaan, dan pasca pembelajaran pada tahap in service learning 1 dan on the job learning. Peserta diklat merespon modul terhadap aspek tampilan, substansi isi, keterbacaan, pedagogis, serta kebermanfaatannya. Peserta diklat memanfaatkan modul dalam kegiatan pembelajaran secara individu, kelompok, dan klasikal pada tahap In service learning 1, On the job learning, In service learning 2, dan setelah menjabat. Faktor-faktor yang mempengaruhi pemanfaatan modul mencakup fasilitator, peserta diklat, suasana dan lingkungan diklat, latar belakang pendidikan, usia serta pengalaman. Kedepannya perlu dilakukan penyempurnaan kualitas keseluruhan modul baik dalam penulisan dan penyajian isi serta cara membelajarkan.
\end{abstract}

Kata Kunci: diklat calon kepala sekolah, kompetensi supervisi, metode deskriptif kualitatif, modul Supervisi Akademik

\section{Analysis of Utilization of Academic Supervision Module in Improving Supervision Competence on the Principal Candidates Training}

\begin{abstract}
This research is motivated by the prrincipal low supervision competency in Principal Competency Test (PCT) in 2015. To increase the competency, it takes various strategic efforts through education and training. The Institute for the Development and Empowerment of School Principals (LPPKS) has conducted a training program for principal candidates since 2010. Implementation of the training program can not be separated from the existence of the module as instrumental input of learning system. However, could the training module provide advantages in improving the competence of training participants? The purpose of this study is to analyze and describe the extent to which the use of academic supervision module in improving the competence of supervision on the principal candidates training. The method in this research is descriptive with qualitative approach. Data collection techniques were conducted through documentation study, interview, and observation. The results show that the academic supervision module was developed by
\end{abstract}


a joint team consisting of academic and practitioner elements and performed by compiling and writing on their own. Layout techniques used in the module are using general standards for scientific paper. The module is used as the main learning material. Before conducting the training, the Master Trainer prepares the learning scenario in the form of RBPMD (Training Program Design) and RP (Learning Plan) with time allocation of 9 JP (hours of lesson). Module is used starting from preparation, execution, and post learning at in-service learning 1 and on the job learning. The training participants respond to the Academic Supervision module on the display aspect, content substance, legibility, pedagogical, and usefulness. Training participants utilize the module in individual, group, and classical learning activities at the In Service learning 1, On the job learning, In service learning 2, and in their tenure. Factors affecting module utilization include facilitators, training participants, education atmosphere and environment, educational background, age and experience. In the future the module needs improvement in overall quality both in terms of writing and presentation of content and learning delivery as well.

Keywords: training for principal candidates, supervision competency, qualitative descriptive method, Academic Supervision module

\section{PENDAHULUAN}

Kepala sekolah memiliki peran yang sangat strategis dalam peningkatan kualitas pendidikan terutama dalam mengupayakan pengembangan sekolah dan perannya sebagai pelaksana delapan standar nasional pendidikan. Peraturan Menteri Pendidikan Nasional Nomor 13 Tahun 2007 tentang Standar Kompetensi Kepala Sekolah/Madrasah menetapkan 5 (lima) dimensi kompetensi yang harus dimiliki oleh seorang kepala sekolah/madrasah meliputi dimensi kompetensi kepribadian, manajerial, supervisi akademik, kewirausahaan, dan sosial.

Kondisi dan situasi yang ada menjadi sebab masing-masing kepala sekolah memiliki perbedaan dalam penguasaan kompetensi yang disyaratkan. Spencer and Spencer dalam Somantrie (2010) menyatakan, "A competency is an underlying characteristic of an individual that is causally related to criterion referenced effective and/or superior

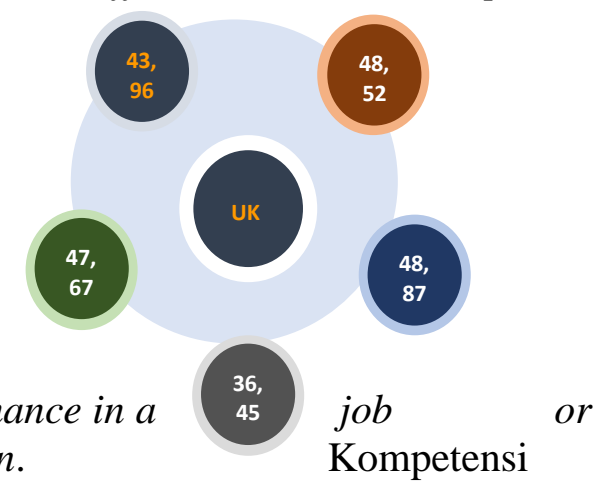

$\begin{array}{ll}\text { performance in } a & \\ \text { situation. } & \text { Kompetensi }\end{array}$ merupakan prasyarat tertentu yang harus dipenuhi oleh seseorang sebelum melakukan sesuatu pekerjaan.
Uji Kompetensi Kepala Sekolah (UKKS) dimaksudkan untuk mengetahui peta penguasaan kepala sekolah pada dimensi kompetensi kewirausahaan, manajerial,supervisi, usaha pengembangan sekolah, dan kepemimpinan pembelajaran. Hasil UKKS Tahun 2015 kepada sebanyak 166.333 orang kepala sekolah yang merupakan $62,62 \%$ dari total kepala sekolah sebanyak 265.635 orang yang disampaikan Direktur Pembinaan Tenaga Kependidikan dalam Kebijakan KSPS Pembelajar di Region Makassar menunjukkan dari lima dimensi kompetensi kepala sekolah, kompetensi supervisi adalah yang paling lemah. Secara rinci paparan hasil UKKS tersebut sebagai berikut.

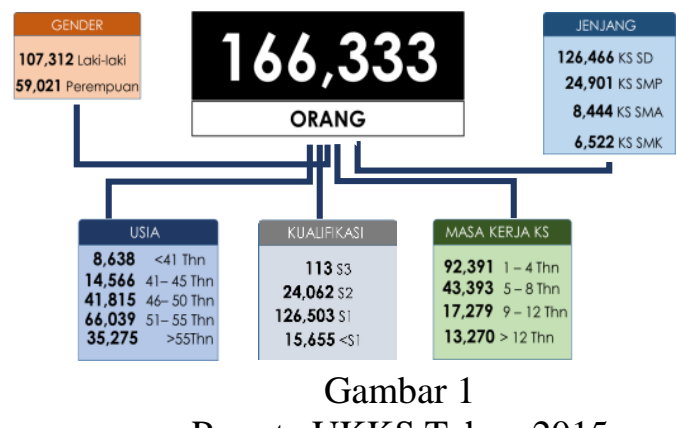

Peserta UKKS Tahun 2015

Sedangkan hasil nilai rata-rata pada setiap dimensi kompetensi pada Uji Kompetensi Kepala Sekolah Tahun 2015 dinyatakan dalam gambar berikut:

KP 
UPS

Supervisi $\quad$ Manajerial

Gambar 2

Nilai Rata-Rata Per Dimensi

Kompetensi supervisi dalam Peraturan Menteri Pendidikan Nasional Nomor 13 Tahun 2007 dijabarkan sebagai berikut: 1) Merencanakan program supervisi akademik dalam rangka peningkatan profesionalisme guru; 2) Melaksanakan supervisi akademik terhadap guru dengan menggunakan pendekatan dan teknik supervisi yang tepat; dan 3) Menindaklanjuti hasil supervisi akademik terhadap guru dalam rangka peningkatan profesionalisme guru.

Upaya meningkatkan hasil uji kompetensi kepala sekolah pada dimensi kompetensi supervisi perlu dilakukan secara terus menerus yaitu melalui diklat.

Diklat Calon Kepala Sekolah (CKS) berdasarkan Peraturan Menteri Pendidikan dan Kebudayaan Nomor 6 Tahun 2018 tentang Penugasan Guru Sebagai Kepala Sekolah merupakan penyiapan kompetensi calon Kepala Sekolah untuk memantapkan wawasan, pengetahuan, sikap, nilai, dan keterampilan dalam memimpin sekolah.

Pelaksanaan diklat tidak dapat dilepaskan dari keberadaan modul sebagai instrumental input dari sistem pembelajaran. Modul merupakan paket program pembelajaran mengenai suatu bahasan tertentu yang dipelajari oleh peserta diklat dengan bantuan minimal dari instruktur/fasilitator untuk mencapai kompetensi/tujuan instruksional yang telah ditentukan. Penggunaan modul dapat mengkondisikan kegiatan pembelajaran agar lebih terencana, mandiri, tuntas dan dengan hasil (output) yang jelas.

Mempertimbangkan pentingnya kompetensi supervisi kepala sekolah, pelaksanaan program diklat calon kepala sekolah yang telah berlangsung selama beberapa tahun serta peranan modul sebagai instrumental input dalam sistem pembelajaran diklat maka peneliti tertarik untuk melakukan penelitian secara mendalam mengenai analisis pemanfaatan modul supervisi akademik dalam meningkatkan kompetensi supervisi pada diklat calon kepala sekolah.

\section{Kajian Pustaka}

\section{Sumber Belajar, Bahan Ajar dan Media Pembelajaran}

"Sumber belajar adalah segala daya yang dapat dimanfaatkan guna memberikan kemudahan kepada seseorang dalam belajarnya" (Wahyudin, 2014: hlm. 181). Siregar dalam Lilawati (2017) mengatakan bahwa sumber belajar merupakan segala sesuatu yang digunakan untuk memfasilitasi belajar. Sedangkan menurut Mulyasa (2002) sumber belajar adalah segala sesuatu yang dapat memberikan kemudahan kepada peserta didik dalam memperoleh sejumlah informasi, pengetahuan, pengalaman, dan keterampilan dalam proses belajar mengajar.

Terdapat enam jenis sumber belajar menurut AECT (Association for Educational Communication and Techology) dalam Rusman (2012), terdiri dari :

a. Pesan (message) adalah informasi yang ditransmisikan atau diteruskan oleh komponen lain dalam bentuk ide, fakta, makna, nilai, dan data. Contoh: bahan pelajaran, cerita rakyat, dongeng dan sebagainya.

b. Manusia (people) yang berperan sebagai pencari, penyimpan, pengolah dan penyaji pesan atau informasi. Tidak termasuk mereka yang menjalankan fungsi pengembangan dan pengelolaan sumber belajar. Contoh; guru, dosen pembimbing, guru pembina, tutor, siswa, pemain, pembicara, instruktur, dan penatar.

c. Bahan (materials) adalah sesuatu (program, media, atau software) yang mengandung pesan untuk disajikan melalui penggunaan alat dirinya sendiri. Contoh: buku, modul, majalah, bahan majalah terprogram, transparansi, film, 
video tape, pita audio (kaset audio), filmstrip dan sebagainya.

d. Alat (device) adalah sesuatu (hardware atau perangkat keras) yang digunakan untuk menyampaikan pesan yang ada didalam bahan. Contoh: slide proyektor, (OHP), monitor televisi, monitor komputer, kaset recorder, kaset radio dan lain-lain.

e. Metode/ teknik (technique) adalah prosedur yang runtut atau acuan yang disiapkan dalam memanfaatkan bahan, peralatan, orang dan lingkungan dalam menyampaikan pesan. Contoh: simulasi, diskusi, ceramah, pemecahan masalah, tanya jawab, dan sebagainya.

f. Lingkungan (setting), yaitu situasi sekitar dimana pesan disampaikan. Contoh: ruangan kelas, studio, aula dan sebagainya.

Secara garis besar, terdapat dua jenis sumber belajar, yaitu 1) sumber belajar yang dirancang (learning resources by design), yakni sumber belajar yang secara khusus dirancang atau dikembangkan sebagai komponen sistem instruksional untuk memberikan fasilitas belajar yang terarah dan bersifat formal; 2) sumber belajar yang dimanfaatkan (learning resources by utilization), yaitu sumber belajar yang tidak didesain khusus untuk keperluan pembelajaran dan keberadaannya dapat ditemukan, diterapkan, dan dimanfaatkan untuk keperluan pembelajaran. (Rusman, 2012; Wahyudin, 2014).

Fungsi sumber belajar menurut Hijrah Saputra dalam Wahyudin (2014) adalah: 1) dapat memberikan pengalaman belajar langsung dan konkret; 2) memungkinkan sesuatu yang tidak bisa diadakan, dikunjungi, dilihat secara langsung; 3) menambah dan memperluas cakrawala sajian; dan 4) memberi informasi yang akurat dan terpadu.

Pengertian bahan ajar menurut Tatang S (2016, hal. 235) adalah "segala bentuk bahan yang digunakan oleh guru/instruktur dalam melaksanakan kegiatan belajar mengajar di kelas. Bahan ajar dapat pula didefinisikan sebagai seperangkat materi yang disusun secara sistematis, baik tertulis maupun tidak sehingga tercipta lingkungan/suasana yang memungkinkan siswa untuk belajar."

Terdapat beberapa ragam bentuk bahan ajar, antara lain:

a. Cetak, misalnya lembar kerja siswa (LKS), handout, buku, modul, brosur, leaflet, dan wallchart.

b. Audio visual, misalnya film/video dan VCD.

c. Audio, misalnya kaset, radio, dan CD audio.

d. Visual, misalnya foto, gambar, dan model/maket

e. Multi media, misalnya CD interaktif, computer based learning, dan internet.

Media adalah teknologi pembawa pesan yang dapat dimanfaatkan untuk keperluan pembelajaran (Scramm dalam Rusman, 2017).

Media pembelajaran dapat dilihat dari dua sudut, yakni: 1) sebagai proses, media berfungsi sebagai alat penunjang proses pembelajaran dalam rangka menyampaian bahan pelajaran kepada siswa untuk mencapai tujuan pengajaran. Bila proses pembelajaran ditunjang oleh media yang serasi, maka keberhasilan belajar siswa dapat tercapai seperti yang diharapkan. 2) sebagai produk, media pembelajaran merupakan hasil kemajuan teknologi. Semakin meningkat kemajuan teknologi, semakin meningkat pula perkembangan media pembelajaran (Hamalik, 1993).

Dilihat dari cara perolehannya terdapat dua jenis media pembelajaran, yaitu media yang bisa langsung dimanfaatkan (by utilization) dan media yang dirancang dan dibuat sendiri (by desain) sesuai dengan kebutuhan.

Modul diambil dari istilah dalam dunia teknologi pendidikan, yang berarti alat ukur yang lengkap. Ada beberapa definisi para ahli tentang modul. Houston \& Howson mengemukakan modul pembelajaran meliputi seperangkat aktivitas yang bertujuan mempermudah siswa untuk mencapai seperangkat tujuan pembelajaran (Nurdin \& Adriantoni, 2016, 
hal. 272). Menurut Kemp (1978) modul diartikan sebagai paket pembelajaran mandiri berisi satu topik atau unit materi pelajaran dan ketentuan waktu yang dibutuhkan untuk mempelajari modul. Sedangkan Robinson \& Crittenden (1972) menjelaskan tentang pengertian modul pembelajaran (learning module) sebagai "A packet of teaching materials consisting of behavioral objectives, a sequence of learning activities, and provision for evaluation."

Vembriarto dalam Jawadha (2015) mengemukakan bahwa modul merupakan suatu paket program pembelajaran yang dapat dipelajari oleh peserta didik dengan bantuan minimal dari instruktur. Suatu modul adalah konsep daripada bahan pelajaran. Sedangkan Purwanto, Rahadi, dan Lasmono (2007) menjelaskan modul adalah bahan belajar cetak yang disusun untuk memudahkan orang dalam mencapai suatu kompetensi atau tujuan instruksional yang telah ditentukan.

Modul memiliki beberapa sifat, diantaranya (Tatang S, 2016): 1) self contained, artinya dikemas dalam satu kesatuan yang utuh untuk mencapai kompetensi tertentu. 2) self instructional, memiliki sifat membantu dan mendorong pembacanya untuk mampu membelajarkan diri sendiri, 3) self alone, tidak bergantung pada media lain dalam penggunaannya, dan 4) self test, memberikan kesempatan kepada peserta didik untuk menguji diri sendiri melalui latihan yang disajikan dalam modul.

Tujuan penyusunan modul menurut Tatang S (2016, hal. 236) salah satunya untuk menyediakan bahan ajar yang sesuai dengan tuntutan kurikulum, dengan mempertimbangkan kebutuhan peserta didik

Purwanto, Rahadi, dan Lasmono (2007) menjelaskan modul dapat dikembangkan dengan berbagai cara antara lain melalui adaptasi, kompilasi dan menulis sendiri. Modul adaptasi adalah bahan belajar yang dikembangkan atas dasar buku yang ada di pasaran. Modul kompilasi ialah bahan belajar yang dikembangkan atas dasar buku-buku yang ada di pasaran, artikel jurnal ilmiah dan modul yang sudah ada sebelumnya. Kompilasi dilakukan oleh guru, dosen atau widyaiswara dengan menggunakan garisgaris besar program pembelajaran/ pelatihan (GBPP). Menulis adalah cara pengembangan modul yang paling ideal karena memiliki tingkat kesulitan tertinggi dibanding dengan kedua cara lainnya.

"Pembelajaran dengan sistem modul biasanya terfokus pada seperangkat kompetensi yang harus dikuasai peserta didik sehingga mampu melakukan aktivitas-aktivitas untuk mencapai tujuantujuan belajar" (Mulyasa, 2009, hal. 235). Sedangkan Sukmadinata dan Syaodih (2012) menjelaskan pembelajaran modul menerapkan strategi belajar siswa aktif: membaca, mencoba, mencari, menganalisis, menyimpulkan, memecahkan masalah sendiri. Pembelajaran modul juga menerapkan konsep multi-metode dan multi-media.

Dalam pemanfaatan modul sebagai sumber belajar diperlukan adanya kemandirian dari setiap individu untuk belajar. Ciri utama belajar mandiri bukan ketiadaan pengajar/instruktur atau tidak adanya tatap muka di kelas namun adanya inisiatif tanggung jawab dan otonomi dari peserta diklat untuk proaktif dalam mengelola proses kegiatan belajarnya.

Abdullah (2012) mengemukakan bahwa peranan sumber belajar erat sekali hubungannya dengan pola pembelajaran yang dilakukan. Pada kegiatan pembelajaran individual, fokusnya adalah peserta didik, sedangkan peranan tenaga pengajar dalam interaksi dengan peserta didik lebih banyak berperan sebagai fasilitator, pengelola belajar, pengarah, pembimbing, dan penerima hasil kemajuan belajar peserta didik.

Atwi Suparman dalam Tatang S (2016, hal. 242-247) memaparkan tentang jenis dan model pembelajaran sebagai berikut: 
1) Model berbagai informasi bertujuan menitikberatkan pada proses komunikasi dan diskusi melalui interaksi argumentatif yang sarat penalaran. Termasuk ke dalam model ini, yaitu model orientasi, sidang umum, seminar, konferensi kerja, simposium, forum, dan panel.

2) Model belajar melalui pengalaman yang tujuannya menitikberatkan pada proses perlibatan dalam situasi yang memberi implikasi perubahan perilaku yang sarat nilai dan sikap sosial. Termasuk ke dalam model ini, yaitu model simulasi, bermain peran, sajian situasi, kelompok aplikasi, sajian konflik, sindikat, dan kelompok "T".

3) Model pemecahan masalah, yang tujuannya menitikberatkan pada proses pengkajian dan pemecahan masalah melalui interaksi dialogis dalam situasi yang sarat penalaran induktif. Termasuk ke dalam model ini, yaitu model curah pendapat, riuh bicara, diskusi bebas, kelompok okupasi, kelompok silang, tutorial, studi kasus, dan lokakarya.

Pemaknaan istilah belajar memiliki keragaman sesuai dengan teori belajar apa yang menjadi rujukannya. Para ahli mengklasifikasikan teori belajar minimal ke dalam: aliran teori behavioristik, aliran teori kognitif dan aliran teori konstruktivis (Rusman, 2017).

Menurut teori belajar behavioristik belajar adalah tingkah laku yang dapat diamati yang disebabkan stimulus dari luar. Sedangkan dalam pandangan konstruktivistik, peserta didik akan belajar dengan baik apabila mereka dapat membawa pembelajaran ke dalam konteks apa yang sedang mereka pelajari ke dalam penerapan kehidupan nyata sehari-hari dan mendapat manfaat bagi dirinya. Menurut konstruktivisme belajar diartikan sebagai kegiatan aktif individu yang belajar untuk melakukan interaksi dengan lingkungannya, sehingga mampu menghayati dan membangun makna terhadap pengalaman tersebut. Menurut Piaget (2000), pelopor teori kognitif, belajar akan lebih berhasil apabila disesuaikan dengan tahap perkembangan kognitif siswa.

Belajar merupakan suatu proses (Purwanto dalam Any, 2011). Sebagai suatu proses didalamnya harus ada yang diproses (masukan atau input) dan hasil dari pemrosesan (keluaran atau output). Faktor-faktor dalam proses belajar mengajar meliputi raw input, instrumental input, environmental input, dan output.

\section{Supervisi Akademik}

Glickman menyatakan supervisi akademik adalah serangkaian kegiatan membantu guru mengembangkan kemampuannya mengelola proses pembelajaran demi pencapaian tujuan pembelajaran (Ambarita, Siburian, dan Purba, 2014, hal. 305). Supervisi akademik menjunjung tinggi praktek perbaikan mutu secara berkesinambungan (continuous quality improvement) sebagai salah satu prinsip dasar dan manajemen terpadu (Hadis dalam Suwartini, 2017).

Sergiovanni dalam (Ambarita, Siburian, dan Purba, 2014; Ditjen PMPTK, 2007) menjelaskan ada tiga tujuan supervisi akademik yaitu penumbuhan motivasi, pengawasan kualitas, dan pengembangan profesionalisme.

Ada bermacam-macam teknik supervisi akademik. Gwyn dalam (Ditjen PMPTK, 2007; Mintadji, 2015) menyatakan teknik-teknik supervisi dapat dikelompokkan menjadi: 1) Teknik supervisi individual, adalah pelaksanaan supervisi yang diberikan kepada guru tertentu yang mempunyai masalah khusus dan bersifat perorangan. Teknik-tekniknya meliputi kunjungan kelas, observasi kelas, pertemuan individual. 2) Teknik supervisi kelompok, adalah satu cara melaksanakan program supervisi yang ditujukan pada dua orang atau lebih. Teknik-tekniknya terdiri atas kerja kelompok, diskusi panel, lokakarya.

\section{Kompetensi Supervisi Kepala Sekolah}

Kompetensi merupakan perpaduan dari pengetahuan, keterampilan, nilai dan sikap 
yang direfleksikan dalam kebiasaan berpikir dan bertindak. McAshan dalam Sanjaya (2005, hal. 6) mengemukakan bahwa kompetensi itu adalah: “... is a knowledge, skills, and abilities or capabilities that a person achieves, which become part of his or her being to the exent he or she can satisfactorily perform particular cognitive, affective, and psychomotor behaviors". Sedangkan Wahyudi dalam Syafmawati (2013) mengartikan kompetensi sebagai kemampuan melaksanakan sesuatu yang diperoleh melalui pendidikan dan latihan dengan standar dan kualitas tertentu sesuai tugas yang akan dilaksanakan.

Supervisi menurut Sergiovani dan Starrat dalam (Mulyasa, 2009, hal. 111; Suryantini, 2016, hal. 10) adalah "Supervision is a process designed to help teacher and supervisor learn more about their practice; to better be able to use their knowledge and skills to better serve parents and schools; and to make the school a more effective learning community." Menurut Sergiovani dan Starrat supervisi merupakan suatu proses yang dirancang secara khusus untuk membantu para guru dan supervisor dalam mempelajar tugas sehari-hari di sekolah; agar dapat menggunakan pengetahuan dan kemampuannya untuk memberikan layanan yang lebih baik pada orang tua peserta didik dan sekolah serta berupaya menjadikan sekolah sebagai masyarakat belajar yang lebih efektif.

Mulyasa dalam Hendarman (2016) menyatakan kepala sekolah melaksanakan kegiatan supervisi secara berkala untuk mengetahui sejauh mana guru mampu melaksanakan pembelajaran. Sedangkan Lasut dalam Iwantoro (2014) mengungkapkan bahwa kepala sekolah sebagai supervisor dibebani peran dan tanggung jawab memantau, membina, dan memperbaiki proses belajar mengajar di kelas atau di sekolah. Seorang kepala sekolah, dalam rangka menjalankan peranperan supervisor akademik, dituntut memiliki keterampilan. Alfonso, Firth, dan
Neville dalam Rifaldi \& Roesminingsih (2014) mengemukakan ada tiga keterampilan yang harus dimiliki oleh supervisor akademik. Pertama, keterampilan teknis (technical skill) berkenaan dengan pengetahuan khusus yang diperlukan untuk memperformakan fungsi-fungsi pokok atau tugas-tugas yang berkenaan dengan posisi supervisor. Kedua, keterampilan hubungan kemanusiaan (human relation skill) berkenaan dengan kemampuan supervisor bekerjasama dengan orang lain dan memotivasi mereka agar bersungguhsungguh dalam bekerja. Ketiga, keterampilan manajerial (managerial skill) - berkenaan dengan kemampuan membuat keputusan dan melihat hubunganhubungan penting dalam mencapai tujuan.

\section{METODE}

Penelitian ini merupakan penelitian deskriptif karena ditujukan untuk mendeskripsikan suatu keadaan atau fenomena-fenomena apa adanya. Peneliti, dalam penelitian ini, tidak melakukan manipulasi atau memberikan perlakuanperlakuan tertentu terhadap objek penelitian. Semua kegiatan atau peristiwa berjalan seperti apa adanya (Sukmadinata, 2017). Penelitian deskriptif ini menggunakan pendekatan kualitatif, penggambaran keadaan secara naratif kualitatif dan dapat dilakukan pada saat ini atau dalam kurun waktu yang singkat. Strategi yang dilakukan pada penelitian ini adalah studi kasus deskriptif. Studi kasus adalah metode untuk menghimpun dan menganalisis data berkenaan dengan sesuatu kasus. Yin (2015) menyatakan studi kasus tidak menunjukkan "sampel" dan bertujuan mengembangkan dan menggeneralisasikan teori (generalisasi analitis) dan bukan menghitung frekuensi (generalisasi statistik). Agar dapat menggali informasi yang lengkap maka penelitian yang dilakukan bersifat eksploratif, yakni menjelaskan suatu fenomena secara lengkap, menyeluruh dan mendalam (Moleong, 2017). 
Penekanan pada perolehan data yang kaya dan mendalam dari sejumlah kecil informan mendorong peneliti untuk berfokus kepada satu lokasi diklat calon kepala sekolah sebagai lokus penelitian. yaitu diklat yang diselenggarakan oleh LPPKS (Lembaga Pengembangan dan Pemberdayaan Kepala Sekolah). Hal ini didasarkan atas berbagai pertimbangan, antara lain: Pertama, LPPKS merupakan leading sector program penyiapan calon kepala sekolah dimana diklat calon kepala sekolah termasuk didalamnya. Kedua, LPPKS juga sebagai salah satu LPD (lembaga penyelenggara diklat) yang terakreditasi untuk menyelengarakan diklat calon kepala sekolah bekerja sama dengan dinas pendidikan kabupaten/kota. Ketiga, diklat calon kepala sekolah yang diselenggarakan oleh LPPKS ini bukan menjadi model praktik terbaik, namun diklat tersebut dapat menjadi gambaran dari diklat-diklat calon kepala sekolah lainnya yang diselenggarakan oleh lembaga penyelenggara diklat calon kepala sekolah lainnya.

Untuk memperoleh data dan informasi yang berkaitan dengan tujuan penelitian, sumber data diambil dari informan kunci (key informant). Informan kunci penelitian ini meliputi Kepala Seksi Peningkatan Kompetensi LPPKS, reviewer modul, Master Trainer, PTP (Pengembang Teknologi Pembelajaran), serta peserta diklat Calon Kepala Sekolah.

Teknik pengumpulan data yang digunakan dalam penelitian ini adalah melalui studi dokumen, observasi, dan wawancara mendalam semi terstruktur (in depth interview). Pengumpulan data dikembangkan melalui pedoman studi dokumen, pedoman observasi, dan pedoman wawancara.

Analisis dokumen menghasilkan informasi yang kontekstual tentang pemanfaatan modul supervisi akademik untuk meningkatkan kompetensi supervisi pada diklat calon kepala sekolah. Dokumen yang dikumpulkan untuk dianalisis meliputi modul cetak supervisi akademik beserta bahan bacaan dan lembar kerja, CD materi modul supervisi akademik, RBPMD (Rancang Bangun Program dan Materi Diklat) dan RP (Rencana Pembelajaran) serta petunjuk pelaksanaan (juklak) dan petunjuk teknik (juknis) diklat calon kepala sekolah.

Penelitian ini menggunakan teknik observasi nonpartisipatif dimana peneliti tidak ikut serta dalam kegiatan dan hanya berperan mengamati kegiatan. Aktifitas yang diobservasi meliputi penggunaan modul, pembelajaran lewat modul, dan interaksi antara ketiga komponen diklat peserta diklat - fasilitator - modul. Observasi difokuskan pada referensi terhadap bukti (ditafsirkan dan diinfomasikan secara luas oleh literatur yang diulas sebelumnya).

Sejumlah informan dipilih berdasarkan jenis kelamin dan unit kerja; Wawancara mendalam baik secara langsung face to face, via telepon, dan email berlangsung selama jam kerja dan berlangsung selama $+/-1$ jam. Wawancara dilaksanakan dalam bahasa Indonesia dan direkam untuk mendapatkan hasil yang akurat.

Data dari sumber dan metode yang berbeda tersebut ditriangulasi untuk meminimalkan bias dalam pengumpulan data dan interpretasi data. Selain itu triangulasi juga ditujukan untuk mengecek keabsahan temuan dan memenuhi kaidah keilmiahan penelitian terkait kevalidan dan kredibilitas data yang dihasilkan. Selain itu peneliti juga melakukan member check, walaupun sudah merupakan hal sesungguhnya dari seorang informan tetapi masih harus dicek dengan informan lainnya dengan prosedur yang sama.

Karakteristik, penggunaan, dan pembelajaran melalui modul supervisi akademik dianalisis untuk menghasilkan deskripsi secara menyeluruh tentang pemanfaatan modul supervisi akademik untuk meningkatkan kompetensi supervisi pada diklat calon kepala sekolah. Analisis penelitian dilakukan dengan teknik interaktif (Miles dan Huberman, 1984). 
Proses analisis interaktif meliputi tahapan: pengumpulan data, reduksi data, penyajian data, dan verifikasi data/penarikan kesimpulan.

Penelitian ini terbagi dalam tiga tahapan sebagaimana disampaikan Moleong (2017) yaitu: tahap pra-lapangan, tahap pekerjaan lapangan, dan tahap analisis data.

Menjaga anonimitas responden dan kerahasiaan adalah aspek-aspek tertentu dari penelitian yang menimbulkan masalah etika tertentu. Mempertimbangkan hal tersebut para responden diberitahu bahwa data tersebut akan disimpan dengan aman dan bahwa publikasi temuan tidak akan melanggar kerahasiaan dan anonimitas yang telah disepakati. Responden berpartisipasi atas dasar itu.

Terdapat beberapa keterbatasan dalam penelitian ini, diantaranya: Pertama, penyelenggaraan diklat calon kepala sekolah bergantung kepada perencanaan yang dibuat oleh instansi ataupun permintaan kerja sama dari dinas pendidikan kabupaten/kota oleh karena itu penelitian ini hanya mengambil satu lokasi diklat. Kedua, keterbatasan dana yang miliki oleh peneliti memaksa peneliti untuk melakukan penelitian di lokasi diklat yang berada di pulau Jawa. Ketiga, pemilihan responden yang berasal dari peserta diklat berdasarkan informasi dan rekomendasi dari fasilitator diklat. Peneliti percaya bahwa dengan menyediakan sejumlah kriteria pemilihan peserta akan memaksimalkan usaha untuk memperoleh responden yang bagus.

\section{HASIL DAN PEMBAHASAN \\ Deskripsi Hasil \\ Profil LPPKS}

LPPKS merupakan Unit Pelaksana Teknis (UPT) dibidang penyiapan, pengembangan dan pemberdayaan kepala sekolah. LPPKS berada di bawah Direktorat Jenderal Guru dan Tenaga Kependidikan dengan struktur organisasi yang terdiri dari Kepala, Kasubbag Umum, Kepala Seksi Sistem Informasi dan Kepala Seksi Peningkatan
Kompetensi serta tenaga fungsional umum dan tertentu.

Visi LPPKS adalah "Menjadi Leading Sector untuk menyiapkan, mengembangkan dan memberdayakan Kepala Sekolah dan Pengawas Sekolah yang Amanah, Berjiwa wirausaha dan Profesional." Layanan program yang ditawarkan LPPKS antara lain: Program Penyiapan Calon Kepala Sekolah/ Madrasah (PPCKS); Program Penyiapan Calon Pengawas Sekolah/Madrasah (PPCPS); Penyiapan Asesor PPCKS; Penyiapan Master Trainer PPCKS; Diklat Manajerial bagi Kepala Sekolah/ Madrasah; Diklat Kemitraan bagi Kepala Sekolah/Madrasah (Program Mentoring Kepala Sekolah); Diklat Supervisi Akademik bagi Kepala Sekolah/Madrasah; Diklat Penguatan Kepala Sekolah/ Madrasah; Diklat Penguatan Pengawas Sekolah/Madrasah.

Penelitian ini berfokus kepada diklat calon kepala sekolah (CKS). Diklat CKS adalah penyiapan kompetensi calon Kepala Sekolah untuk memantapkan wawasan, pengetahuan, sikap, nilai, dan keterampilan dalam memimpin sekolah. Diklat CKS dikemas dalam 4 tahap: penyusunan program diklat, kegiatan InService Learning 1 (IN-1), On-the-Job Learning (OJL), dan In-Service Learning 2 (IN-2).

Diklat CKS yang dibahas dalam penelitian ini adalah diklat CKS yang diselenggarakan oleh LPPKS bekerjasama dengan BKD Kabupaten Tasikmalaya. Diklat CKS kabupaten Tasikmalaya diselenggarakan di Hotel Mangkubumi, Tasikmalaya selama 7 (tujuh) hari pada Selasa sampai dengan Senin, 6-12 Maret 2018. Peserta diklat CKS berjumlah 90 orang yang terbagi ke dalam 3 kelas. Masing-masing kelas diampu oleh 2 (dua) orang Master Trainer yang berasal dari unsur Widyaiswara LPPKS dan Pengawas Sekolah. Peserta terdiri dari guru-guru jenjang SD dan SMP. Diklat CKS dilaksanakan selama 70 jam pelajaran. Pelaksanaan diklat CKS Kabupaten 
Tasikmalaya menggunakan modul bahan ajar sebanyak 12 (dua belas) buah.

\section{Pemanfaatan Modul Supervisi Akademik dalam Meningkatkan Kompetensi Supervisi pada Diklat Calon Kepala Sekolah}

Karakteristik Modul yang Digunakan pada Diklat Calon Kepala Sekolah

Komponen dan sistematika modul pada diklat CKS telah memenuhi karakteristik yang harus ada pada modul yaitu terdiri dari Kata Pengantar, Daftar Isi, Penjelasan Umum (pengantar bahan pembelajaran, hasil pembelajaran yang diharapkan, tagihan, ruang lingkup, dan langkah-langkah pembelajaran), Kegiatan In Service Learning 1 (Kegiatan Pembelajaran 1, Kegiatan Pembelajaran 2, Kegiatan Pembelajaran 3, Refleksi, Simpulan), Kegiatan On the Job Learning, Kegiatan In Service Learning 2, Daftar Pustaka, Glosarium, Bahan Bacaan, dan Lampiran.

“... Di sistematika ada namanya penjelasan umum, kegiatan 1 , di situ ada KB KB 1,2,3 lalu ada refleksi ada simpulan. Kemudian ada juga kegiatan OJLnya, kegiatan In-2nya diperintahkan mengerjakan apa, lalu daftar pustakanya ada, glosariumnya ada, bahan bacaannya itu juga ada apa saja yang bisa melengkapi wawasan supervisi akademik jadi tidak sekedar daftar pustaka tapi juga ada bahan bacaan ditaruh di file tidak di modul ini... Lampirannya juga banyak tentang instrumen-instrumen yang digunakan."

LPPKS mengembangkan kedua belas modul pembelajaran pada diklat CKS dengan melalui beberapa tahap. Pertama, LPPKS menyusun UoL (Unit of Learning) yang menjelaskan mengenai kompetensi yang harus dimiliki oleh seorang calon kepala sekolah berdasarkan Peraturan Menteri Pendidikan Nasional Nomor 13 Tahun 2007 tentang Standar Kompetensi Kepala Sekolah. Kemudian modul dikembangkan dengan mengkombinasikan beberapa cara yaitu dengan cara mengkompilasi dari berbagai referensi seperti buku, jurnal, dan modul penguatan lainnya serta dengan cara menulis sendiri berdasarkan dari hasil pengalaman penulis modul. Selanjutnya dalam perkembangan dan penerapannya dilakukan beberapa kali revisi guna menyesuaikan dengan peraturan perundang-undangan yang terbaru. Modul diklat CKS dikembangkan oleh tim gabungan yang terdiri atas unsur akademisi yaitu para dosen dan unsur praktisi yang meliputi kepala sekolah, pengawas sekolah serta widyaiswara.

"Sesuai dengan Permendikbud No. 13 Tahun 2007. Modul mengikuti itu KB 1 perencanaan supervisi. KB 2 penerapan teknik-teknik supervisi dan KB 3 tindak lanjut hasil supervisi ... Gabungan. Pertama dari UoLnya dari pusat kemudian dikembangkan oleh akademisi dan praktisi. Penyusun dan pengembang modul dari kalangan akademisi yaitu dari universitas. Kemudian praktisi ada KS dan PS. Tiga-tiganya. Kalo kompilasi dari adaptasi maupun pengembangan berdasarkan dari akademis sendiri. Jadi penulis dari kalangan akademisi (kampus) itu membawa mindset tentang konten supervisi dari segi keilmuan. Kemudian yang dari praktisi KS, PS maupun WI itu berdasarkan pengalaman supervisi bagaimana dilaksanakan. Nah kedua hal ini berdasarkan pengalaman dan kajian teori yang ada maka dimixkan di kompilasikan menjadi modul."

Adapun teknik layout yang digunakan dalam pembuatan modul mengacu pada standar lppks. Layout isi modul berpedoman kepada aturan penulisan karya tulis ilmiah.

"Teknik layout yang digunakan hanya menggunakan layout standar dalam membuat buku ukuran A4 dengan microsoft word. Kemudian untuk mengamankan dari perubahan layout dibuat dalam format .pdf baru dikirim ke percetakan untuk dicetak. Layout isi modul menggunakan standar yang dimiliki oleh LPPKS dengan berpedoman pada aturan penulisan skripsi atau tesis dengan menentukan 
batas atas, bawah, kiri, dan kanan. Jenis huruf 'Arial'. Ukuran huruf untuk judul bab 14, sub judul 12 dan materi 11. Kemudian spasi menggunakan 1.5 spasi. Standar mengenai aturan penulisan dan juga struktur modul memiliki ciri sendiri yang menjadi kekhasan modul LPPKS. Cover modul didesain dengan menggunakan coreldraw kemudian hasilnya diubah kebentuk .jpg kemudian dimasukkan ke dalam microsoft word. Cover dibuat dengan latar belakang gedung LPPKS dan judul menggunakan jenis huruf Arial. Alasan menggunakan microsoft word dikarenakan agar memudahkan ketika melakukan revisi baik isi maupun bahasa."

Terdapat berbagai pandangan dari para responden tentang penggunaan modul diklat calon kepala sekolah. Ada yang berpendapat modul sebagai bahan utama,

"Ini sebagai bahan utama bukan kelengkapan. Bahan utama itu - fokus utama pembelajaran ada di modul baru dilengkapi dengan bahan tayang. Bahan tayang itu media yang digunakan oleh MT untuk menyampaikan isi modul. Sebenarnya bahan tayang itu hanya merupakan pelengkap dari modul yang ada tapi fokus utama konten yang ada itu di modul."

Responden lainnya menyatakan
modul sebagai bahan pendukung:
"...dalam proses diklat ini ya dipakai
acuan sebagai proses pembelajaran..."

Ada pula responden yang mengemukakan modul sebagai salah satu sumber belajar,

"Salah satu sumber belajar mengingat bahwa mereka juga diberikan CD yang dalam CD ini ada banyak sekali sumber belajar yang lain seperti peraturan perundang-undangan. Ada banyak regulasi yang harus mereka kaji dan dalami termasuk juga power point jadi merupakan salah satu sumber belajar mereka, bukan satu-satunya."

Rencana Pembelajaran melalui Pemanfaatan Modul Supervisi Akademik pada Diklat Calon Kepala Sekolah
Sebelum melaksanakan diklat CKS, Master Trainer harus mempersiapkan skenario pembelajaran dalam bentuk RBPMD (Rancang Bangun Program Mata Diklat) dan RP (Rencana Pembelajaran) dengan alokasi waktu sebanyak 9 JP (jam pelajaran). Adapun sistematika perencanaan pembelajaran pada diklat CKS mengacu kepada panduan dari LAN (Lembaga Administrasi Negara).

"Kalo dalam rancangan pembelajaran MT itu mengikuti RBPMD... Sistematikanya kami menggunakan dari LAN dimana di awal-awal itu ada identitas mata diklat, karakteristiknya mulai dari tujuannya, kemudian ruang lingkup materi dst. Itu di identitas. Kemudian baru di langkah-langkah pembelajaran mulai dari indikator ketercapaian tujuan, kemudian kegiatan awalnya bagaimana, kegiatan intinya bagaimana, kegiatan penutup, kemudian penilaiannya bagaimana. Itu di rancang bangun."

RBPMD Supervisi Akademik memuat media dan sumber belajar yang bervariasi dan sesuai dengan karakteristik mata diklat, yaitu modul cetak beserta CD materi yang berisi instrumen supervisi akademik: form1, form2, form3 dan form 4; contoh: perangkat pembelajaran (RKMRKH, Silabus/RPP); video pembelajaran berdurasi pendek; form instrumen penilaian:form:1, form:2, form:3, dan form: 4, LK (lembar kerja), laptop, dan LCD.

Evaluasi pembelajaran supervisi akademik yang termuat dalam rencana pembelajaran meliputi penilaian terhadap aspek pengetahuan melalui tes awal, tes akhir, dan hasil diskusi peserta tentang konsep supervisi akademik; penilaian terhadap aspek sikap berdasarkan observasi terhadap perilaku peserta mengacu kepada PPK; penilaian terhadap aspek keterampilan melalui unjuk kerja penerapan supervisi dan penugasanpenugasan yang diberikan. Selain itu juga terdapat evaluasi terhadap narasumber dan evaluasi penyelenggaraan diklat. 
"Kalo evaluasinya di dalam proses digunakan evaluasi skill atau keterampilan peserta bagaimana cara menerapkan teknik-teknik supervisi lewat simulasi-simulasi dalam supervisi itu dinilai hasil kerja mereka. Yang kedua penilaian pengetahuan lewat hasil diskusi bersama tentang konsep supervisi akademik. Yang pengetahuan tertulis, yang keterampilan itu berdasarkan pengamatan atau unjuk kerja."

Adapun strategi pembelajaran yang direncanakan untuk diterapkan meliputi brainstorming (curah gagasan) dan eksplorasi mengenai pengalaman peserta disupervisi oleh kepala sekolahnya, diskusi kelompok dan kelas, tanya jawab, ceramah, penugasan individu dan kelompok dalam pengerjaan LK, presentasi, roleplay (bermain peran) serta simulasi: "Di modul itu macamnya banyak. Ada eksplorasi ada diskusi kelompok, ada tanya jawab, ada macam macam, kan."

Selesai pembelajaran tatap muka pada tahap In-1 terdapat tindak lanjut pembelajaran yaitu peserta diklat menyusun program dan mempraktikkan program supervisi kepada guru junior di sekolah magang sendiri selama 3 (tiga) bulan pada saat OJL.

"Kalo kita karena polanya In-On-In jadi setelah In-1 itu ada penugasan supervisi di On-nya setelah ada ilmu yang mereka dapatkan ketika In, mereka terapkan di On-nya. Jadi mereka di lapangan di sekolah sendiri akan mencoba untuk menyusun program untuk dua kepala sekolah yang akan mereka supervisi langsung. Kemudian mereka melaksanakan supervisi terhadap 2 (dua) guru junior. Disimulasikan semua dari mulai menyusun programnya, bagaimana caranya mereka mendampingi ketika guru menyusun RPP, lalu RPPnya udah benar belum cara memberikan feedback kepada superviseenya. lalu ketika gurunya mengajar mereka mengamati di kelas sambil mencatat di instrumen pengamatannya. Setelah selesai diobservasi mereka janjian sama gurunya, diskusi masalah feedbacknya itu. Apa yang terjadi tadi di ruang kelas, apa yang udah bagus, apa yang belum bagus lalu didiskusikan disitu. Kemudian ada rancangan tindak lanjutnya seperti apa supervisor ke superviseenya setelah melakukan pengamatan di kelas."

\section{Langkah-Langkah Pemanfaatan Modul Supervisi Akademik pada Diklat Calon Kepala Sekolah}

Dari hasil analisis dokumen modul Supervisi Akademik (sebagaimana terlampir) diperoleh informasi mengenai langkah-langkah yang harus dilakukan peserta diklat dalam melaksanakan pembelajaran modul supervisi akademik ini mencakup aktivitas individual dan kelompok. Adapun aktivitas individu dan kelompok saat In-1 meliputi: 1) membaca bahan pembelajaran; 2) mengamati dan mendiskusikan video pembelajaran, mengerjakan latihan/tugas memecahkan studi kasus pada setiap kegiatan belajar; 3 ) membuat rangkuman/kesimpulan; mengomunikasikan hasil diskusi; dan 5) melakukan refleksi. Kemudian langkahlangkah yang harus dilakukan pasca pembelajaran modul supervisi akademik ini mencakup aktivitas secara individu dan kelompok selama OJL, yaitu: 1) menyiapkan rencana program supervisi akademik dan instrumen supervisi akademik; 2) berkoordinasi dengan kepala sekolah untuk mengimplementasikan supervisi akademik; 3) melakukan supervisi akademik terhadap seorang guru junior di sekolah sendiri secara komprehensif, minimal 2 (dua) kali supervisi akademik; dan 4) membuat laporan tertulis pelaksanaan supervisi akademik guru junior untuk dipresentasikan pada saat In-2. Khusus CKS yang hasil AKPKnya (Analisis Kebutuhan Pengembangan Keprofesian) rendah pada kompetensi supervisi, maka wajib melakukan peningkatan kompetensi 
supervisi akademik di sekolah kedua (sekolah lain).

Pada diklat CKS Kabupaten Tasikmalaya, seluruh responden sepakat bahwa modul supervisi akademik digunakan mulai dari persiapan, pelaksanaan, dan pasca pembelajaran pada tahap in service learning 1 dan pada tahap on the job learning baik oleh Master Trainer maupun oleh peserta diklat.

"MT dalam menyiapkan diri membaca modul yang ada. Modul digunakan atau dipelajari oleh MT sehingga ketika bahan tayang itu ditayangkan maka MT mengetahui makna dari setiap slide di bahan tayang dari hasil membaca modul. ... bagi peserta, modul secara hard copy dan soft copy, sebelum dilakukan proses pembelajaran supervisi, sudah dibagi sehingga menjadi bekal mereka membaca-baca dulu. Jadi ketika JPnya mulai mereka sudah memiliki wawasan tentang supervisi...Kalo di modul itu sendiri itu sudah ada kegiatan di depannya, sudah ada kegiatan di In-1, setelah In-1, Anda akan melakukan On dengan tugas-tugas sebagai berikut. Kemudian setelah On, Anda akan In-2. yang akan dipresentasikan di In-2 adalah $\mathrm{A}, \mathrm{B}, \mathrm{C}, \mathrm{D}$ sudah dijelaskan dimodulnya"

Kemudian langkah-langkah pelaksanaan pembelajaran modul meliputi aktivitas individu dan kelompok.

"Kalo dalam pelaksanaan pembelajaran modul itu digunakan ketika peserta diklat harus menggali informasi tentang supervisi lewat aktivitas individu maupun kelompok dan harus menemukan sendiri tidak lewat pemberitahuan atau bahan tayang dari trainer... Di awal ada semacam brainstorming untuk mengetahui sejauh mana kemampuan para peserta diklat terkait dengan konsep supervisi akademik... Kemudian di tengahnya ada studi kasus yang mereka harus kaji. Kemudian juga harus ada praktek melakukan supervisi. Kemudian ada praktek simulasi tentang pra- dan post observasi misalnya seperti itu. Jadi sembilan jam itu berurutan."
Selanjutnya langkah-langkah pasca pembelajaran modul yaitu berkaitan dengan tahap OJL. Oleh karena itu sekali lagi peserta diklat mau tidak mau akan membaca modul Supervisi Akademik kembali untuk memastikan diri bahwa langkah-langkah yang akan ditempuh saat pengimplementasian supervisi nanti di lapangan sudah memenuhi aturan.

"Setelah pembelajaran selesai ada tugastugas berikutnya yaitu membuat program supervisi, harus melaksanakan di sekolah magang sekolah sendiri. Nah modul dibaca-baca kembali oleh peserta agar mengingat kembali apa yang sudah dipelajari di dalam kelas. Sehinggga ketika pelaksanaan di magang itu akan lancar sesuai dengan rambu-rambu yang ada."

Guna menunjang pelaksanaan kegiatan pembelajaran modul dengan lancar maka setiap pihak harus terlibat aktif diantaranya master trainer, peserta diklat serta panitia LPPKS, dinas maupun BKD.

Respon Peserta Diklat terhadap Modul Supervisi Akademik dalam Meningkatkan Kompetensi Supervisi pada Diklat Calon Kepala Sekolah

Respon peserta diklat terhadap aspek tampilan modul Supervisi Akademik yaitu diharapkan cover modul dapat menunjukkan konten dari modul tersebut. Sedangkan berkaitan dengan aspek substansi isi modul peserta diklat menunjukkan respon yang positif karena modul tersebut memberikan peserta diklat wawasan dan pemahaman yang benar dan tepat tentang serba serbi supervisi akademik. Selanjutnya mengenai aspek keterbacaan modul, peserta diklat berbeda pendapat tentang kejelasan tulisan. Lebih lanjut modul hendaklah menggunakan bahasa yang sederhana yang dapat dipahami oleh semua guru dari berbagai jenjang.

"Modul supervisi selalu mengalami perkembangan dari tahun ke tahun. Terhadap templatenya mereka ada masukan-masukan seperti layout yang 
digunakan, gambar yang digunakan di sampul. Di sampul itu LPPKS menampilkan gedung LPPKS. Jadi begitu membuka modul oh ini modul LPPKS bukan kesannya ini modul supervisi. Untuk kesan yang pertama sebenarnya cover harusnya menunjukkan konten."

Terkait dengan aspek pedagogis modul, diharapkan strategi pembelajaran modul dapat dilakukan secara andragogi yaitu dengan cara peserta menggali informasi serta perpaduan antara teori dan praktik. Selain itu modul Supervisi Akademik juga diharapkan dapat dipelajari secara mandiri dan mempertimbangkan inklusi sosial dengan tidak membedakan suku, agama, ras, gender, dan status sosial. Pada akhirnya peserta diklat menyatakan banyaknya manfaat yang dapat mereka peroleh dari pembelajaran modul supervisi akademik untuk meningkatkan kompetensi supervisi mulai dari menyusun, melaksanakan di lapangan dan menindaklanjuti program supervisi. Modul Supervisi Akademik juga telah mengakomodir berbagai karakteristik peserta diklat dalam hal cara belajar baik visual, auditori, dan kinestetik serta pembelajaran orang dewasa (andragogi). Di samping itu modul Supervisi Akademik juga merangsang peserta untuk dapat mempelajarinya secara mandiri. Pandangan lainnya mengenai aspek kebermanfaatan modul Supervisi Akademik pada penerapan dilapangan setelah menjabat dapat diperoleh melalui alumni.

"Dari itu sudah sangat jelas, Bu. Membantu kamilah dari segi pedagogiknya dimana pengetahuan tentang evaluasi akademis ternyata disitu banyak langkah-langkah atupun teknik evaluasi. Itu kalo di lapangan ternyata bukan supervisi ternyata setelah melihat dari modul oh ternyata itu juga termasuk sebagai salah satu supervisi. Jadi untuk secara pedagogisnya banyak sekali membantu kami...ya karena isinya ada langkah-langkah yang harus ditempuh oleh kita. Jadi terinci sekali... Hanya tulisannya kadang ada yang merasa kecil-kecil, fontnya begitu. Ada kalimat yang ambigu."

Cara Peserta Diklat Memanfaatkan Modul Supervisi Akademik dalam Meningkatkan Kompetensi Supervisi pada Diklat Calon Kepala Sekolah

Peserta diklat dalam memanfaatkan modul baik dalam kegiatan pembelajaran secara individu, kelompok, dan klasikal pada tahap In service learning 1 yaitu dengan cara mengerjakan LK-LK yang terdapat di dalam modul. Pada tahap On the job learning peserta diklat dapat membuka dan mempelajari modul kembali untuk memastikan bahwa mereka telah memahami langkah-langkah supervisi secara benar dan tepat saat melakukan kegiatan supervisi terhadap guru junior. Sedangkan pada tahap In service learning 2 , peserta dapat mensinkronkan antara apa yang sudah dilakukan dengan teori atau sumber yang ada di modul sehingga dapat membuat laporan dengan baik. Pemanfaatan modul Supervisi Akademik bahkan terjadi pasca In service learning 2 yaitu ketika peserta diklat telah menjabat sebagai kepala sekolah.

"Kalo modul ini bukan hanya di In-1, nanti akan digunakan pula sebagai pegangan peserta saat OJL. Ya sebab bayangkan kalo modul hanya dibaca dalam waktu 9 JP. Nah saat OJL nanti itu mereka akan mempedomani modul ini lagi disamping informasi yang dilakukan secara lisan oleh para MT. In2 yang akan dilakukan setelah OJL selesai ya mereka nanti sudah lagi tidak pegang modul tetapi pegang laporan yang berupa portofolio dan juga berupa presentasi power point. In ke-2 itu kan laporan. Peserta akan pertanggungjawabkan satu satu. Coba langkah-langkahnya mensupervisi misalnya seperti apa ditanya misalnya seperti itu. Sesuai gak dengan teori yang diberikan saat belajar di In-1 pada modul. Berarti kan tetap bisa dipakai. Ya nanti setelah peserta melaksanakan tugas sebagai kepala sekolah. karena ini praktis pedoman praktis." 
Faktor-faktor yang Mempengaruhi Pemanfaatan Modul Supervisi Akademik dalam Meningkatkan Kompetensi Supervisi pada Diklat Calon Kepala Sekolah

Faktor-faktor yang mempengaruhi pemanfaatan modul mencakup fasilitator, peserta diklat, suasana dan lingkungan diklat, latar belakang pendidikan serta usia.

Data menunjukkan bahwa fasilitator mempengaruhi pemanfaatan modul. Modul Supervisi Akademik bukan digunakan untuk belajar mandiri tetapi modul memerlukan trainer atau fasilitator untuk menyampaikan isi kepada peserta. Jika peserta mempelajari modul secara mandiri akan menerima informasi yang boleh jadi berbeda dengan apa yang diharapkan dari isi modul. Fasilitator berfungsi sebagai media penjelas yang memfasilitasi agar modul supervisi akademik ini bisa dicerna oleh para peserta diklat.

Faktor lainnya yang mempengaruhi adalah peserta diklat. Hal tersebut berkaitan dengan daya tangkap, keaktifan dalam mengakses modul ataupun berdiskusi. Peserta diklat merupakan pengguna yang secara otomatis akan membawa pengaruh terhadap pengembangan modul ke depan.

Suasana serta lingkungan diklat juga turut mempengaruhi proses pembelajaran modul dan juga juga berkontribusi terhadap kelancaran proses pembelajaran melalui modul. Suasana diklat CKS di lokasi yang berada di pinggiran kota membuat udara menjadi segar dan jauh dari kebisingan. Hal ini membantu peserta untuk dapat lebih fokus dalam mempelajari modul. Ruangan kelas yang sempit dengan pengaturan meja memanjang atau melingkar mempengaruhi pembelajaran modul terutama pada pembelajaran secara berkelompok.

Terkait dengan faktor latar belakang pendidikan mempengaruhi karena berkaitan dengan kecepatan dan daya serap dan daya analisis dalam memahami materi terutama untuk peserta dengan jenjang pendidikan dasar yang umumnya memiliki literasi TIK yang rendah.

Usia mempengaruhi karena berkaitan dengan daya tangkap, daya ingat, stamina, dan produktivitas. Usia berbanding lurus dengan proses penyerapan pembelajaran melalui modul.

Hal baru yang muncul mempengaruhi penguasaan supervisi justru pengalaman yaitu pengalaman ketika mereka menjadi guru yang disupervisi oleh kepala sekolahnya.

\section{Pembahasan}

Hasan (2014) mengemukakan bahwa kegiatan utama diklat ditandai oleh adanya interaksi dan komunikasi yang sangat terencana antara dua komponen pendidikan yang utama yaitu pengajar/fasilitator dan peserta diklat dengan sumber belajar.

Sumber belajar dimanfaatkan untuk kegiatan belajar dengan asumsi bahwa sumber belajar tersebut memiliki fungsi. Depdikbud dalam Purnama (2012) mengungkapkan fungsi-fungsi tersebut, yaitu: 1) Untuk meningkatkan produktifitas pendidikan, dimana sumber belajar diharapkan dapat memicu produktifitas semua aspek dalam pendidikan; 2) Untuk memberikan kemungkinan pendidikan yang lebih bersifat individual, sumber belajar dimungkinkan dapat dipakai secara mandiri untuk kegiatan belajar; 3) Untuk lebih memantapkan pengajaran, dengan sumber belajar yang dipakai maka pembelajaran akan semakin jelas untuk dapat diterima oleh peserta didik, sehingga akan menumbuhkan minat dan motivasi siswa; 4) Untuk memungkinkan belajar secara seketika, dengan adanya sumber belajar yang bisa dipakai maka akan menghilangkan jarak dan waktu untuk belajar, sehingga siswa dapat belajar setiap saat dan di semua tempat; 5) Untuk memungkinkan penyajian pendidikan yang lebih luas.

Salah satu sumber belajar yang banyak digunakan dalam pelaksanaan 
diklat adalah sumber belajar berbentuk bahan yaitu modul. Purwanto, Rahadi, dan Lasmono (2007) menjelaskan modul adalah bahan belajar cetak yang disusun untuk memudahkan orang dalam mencapai suatu kompetensi atau tujuan instruksional yang telah ditentukan. Finch \& Crunkilton dalam Mulyasa (2008, hal.38) mengartikan kompetensi sebagai "penguasaan terhadap suatu tugas, keterampilan, sikap, dan apresiasi yang diperlukan untuk menunjang keberhasilan."

Modul supervisi akademik bertujuan untuk mempermudah peserta diklat dalam mencapai tujuan instruksional berupa kompetensi supervisi yaitu merencanakan, melaksanakan, dan menindaklanjuti program supervisi. Keberhasilan sekolah untuk meningkatkan kinerja siswa bergantung pada kompetensi kepala sekolah (Barnard dalam Mustamin dan Yasin, 2012).

Pembelajaran modul ditandai dengan ciri-ciri sebagaimana dikemukakan Nurdin \& Adriantoni (2016: 273) sebagai berikut: 1) bersifat self-instructional; 2) pengakuan atas perbedaan-perbedaan individual; 3) memuat rumusan tujuan pengajaran secara eksplisit; 4) adanya asosiasi, struktur dan urutan pengetahuan; 5) penggunaan berbagai macam media (multimedia); 6) partisipasi aktif dari peserta diklat; 7) adanya reinforcement langsung terhadap respons peserta diklat; 8) adanya evaluasi terhadap penguasaan peserta diklat atas hasil belajarnya.

Modul Supervisi Akademik disusun dengan tujuan sebagaimana dinyatakan oleh Purwanto, Rahadi, dan Lasmono (2007, hal. 165): Pertama, modul disusun untuk memudahkan peserta diklat dalam mempelajari bahan belajar sehingga menguasai kompetensi supervisi. Kedua, isi modul disajikan untuk peserta diklat dengan asumsi mereka dapat mempelajarinya secara individu atau secara mandiri. Ketiga, modul ditulis untuk membimbing dan mengarahkan proses belajar, termasuk proses diklat. Selain itu, yang keempat, modul disusun agar dapat meningkatkan kesiapan (readiness) peserta diklat agar mereka dapat belajar secara lebih terarah, dan terprogram, sehingga proses belajar (proses diklat) menjadi lebih efektif dan efisien. Selain itu modul Supervisi Akademik disusun untuk menyediakan bahan ajar yang sesuai dengan tuntutan kurikulum, dengan mempertimbangkan kebutuhan peserta diklat.

Modul Supervisi Akademik dikembangkan melalui adaptasi, kompilasi dan menulis sendiri sebagaimana yang dinyatakan oleh Purwanto, Rahadi, dan Lasmono (2007). Modul dikembangkan berdasarkan buku-buku artikel jurnal ilmiah dan modul yang sudah ada sebelumnya yang berkaitan dengan supervisi dan perkepalasekolahan. Modul dikompilasi oleh tim penulis dengan menggunakan garis-garis besar program pembelajaran/pelatihan (GBPP) atau silabi yang disusun sebelumnya. Tim penulis modul yang terdiri dari unsur akademisi (dosen) dan praktisi (kepala sekolah, pengawas sekolah, dan widyaiswara) yang menguasai tentang dunia perkepalasekolahan dan supervisi serta memiliki kemampuan menulis. Hal tersebut merupakan prasyarat yang harus dipenuhi agar dapat dihasilkan modul yang baik yang berisi ide dan pengalamanpengalaman terbaik mereka.

LPPKS menggunakan sistem pembelajaran mandiri dengan menggunakan modul pembelajaran pada diklat calon kepala sekolah adalah karena diklat tersebut merupakan salah satu bentuk pendidikan orang dewasa (andragogi). Knowles dalam Danim (2013) memberikan contoh penerapan prinsipprinsip andragogi dengan desain pelatihan seperti berikut ini:

a) Ada kebutuhan untuk menjelaskan mengapa hal-hal tertentu yang diajarkan, misalnya perintah tertentu, fungsi, operasi, dan lain-lain.

b) Pengajaran harus berorientasi pada tugas yang bermakna, bukan menghafal. Kegiatan belajar harus 
berada dalam konteks tugas umum yang akan dilakukan.

c) Pengajaran harus mempertimbangkan berbagai latar belakang yang berbeda dari peserta didik, bahan belajar dan kegiatan harus memungkinkan berbagai tingkat atau jenis pengalaman sebelumnya.

d) Karena orang dewasa cenderung mandiri, pengajaran harus memungkinkan pembelajar menemukan hal-hal untuk diri mereka sendiri, memberikan bimbingan dan bantuan ketika ada kesalahan yang dibuat.

Sistem belajar mandiri menuntut adanya materi pembelajaran yang dirancang khusus untuk belajar mandiri. Oleh karena itu, penyusunan materi diklat harus memenuhi kriteria berikut: a) kejelasan rumusan tujuan pembelajaran (umum dan khusus), b) materi pembelajaran dikembangkan setahap demi setahap, dikemas mengikuti alur desain pesan, seperti keseimbangan pesan verbal dan visual, c) materi pembelajaran merupakan sistem pembelajaran lengkap, yaitu adanya rumusan tujuan belajar, materi pembelajaran, contoh/bukan contoh, evaluasi penguasaan materi, petunjuk belajar dan rujukan bacaan, d) materi pembelajaran dapat disampaikan kepada peserta didik melalui media komunikasi, atau komputerisasi, seperti: modul, CD-ROM, atau program audio/video, e) materi pembelajaran dikirim dengan jasa pos, atau menggunakan internet (situs tertentu) dan email; atau dengan cara lain yang mudah dan terjangkau oleh peserta didik, f) penyampaian materi pembelajaran dapat pula disertai dengan kegiatan tutorial, yang diselenggarakan berdasarkan jadwal dan lokasi tertentu atau sesuai dengan kesepakatana bersama (Prawiladilaga, 2004).

Materi pembelajaran mandiri atau modul dirancang bagi peserta pelatihan untuk belajar secara individu dengan bantuan lebih sedikit dari orang lain.
Kegiatan terpadu di dalam modul harus mampu menciptakan situasi tertentu yang serupa dengan aktivitas belajar di kelas. Salah satu rangsangannya adalah pertanyaan atau bentuk latihan. Pertanyaan dan aktivitas dalam modul dapat dibangun untuk mengembalikan dialog antara instruktur dan peserta pelatihan terjadi dalam aktivitas belajar (Grange, Briggs and Wager, 1992 dalam Rahman, 2015).

Rusman (2012, hal. 143-145) mengemukakan strategi dalam merancang sumber belajar, seorang instruktur harus mampu mengidentifikasi berbagai karakteristik sumber belajar yang digunakan. Langkah-langkah yang harus dilakukan adalah sebagai berikut: a) Instruktur harus mengidentifikasi karakteristik sumber belajar yang akan digunakan, b) Sumber belajar yang digunakan disesuaikan dengan tujuan pembelajaran, c) Sumber belajar yang digunakan disesuaikan dengan kemampuan instruktur, d) Sumber belajar yang digunakan disesuaikan dengan kebutuhan siswa.

Seorang instruktur, dalam pelaksanaan merancang sumber belajar harus memerhatikan kedudukan sumber belajar yang akan dimanfaatkan dalam proses pembelajaran (Rusman, 2012). Apakah sumber belajar itu kedudukannya sebagai total teaching (menggantikan instruktur secara total dalam proses pembelajaran), major resources (menunjang sebagian besar proses pembelajaran, guru berperan sebagai pemandu), atau hanya sebagai suplement view (peranan instruktur masih dominan, sumber belajar hanya sebagai penunjang).

Dalam pelaksanaan merancang sumber belajar sebagai major resources harus diperhatikan hal-hal sebagai berikut:

1) Di awal proses pembelajaran, upaya instruktur untuk memusatkan perhatian dan memberikan informasi awal bagi para peserta diklat terhadap materi pelajaran yang akan disajikan melalui kegiatan apersepsi. 
2) Di dalam proses pembelajaran, yang sedang berlangsung dikombinasikan secara fungsional dan proporsional dengan penjelasan yang sedang disampaikan oleh instruktur. Di dalam bentuk kegiatan ini penyajian sumber belajar dapat dapat dilakukan oleh narasumber atau sumber belajar utama untuk merangsang para peserta diklat untuk lebih mendalami materi pelajaran yang sedang disajikan.

3) $\mathrm{Di}$ akhir proses pembelajaran instruktur memberi kesempatan dan peluang kepada para peserta diklat untuk mengkaji dan menelaah serta menyimpulkan materi pelajaran yang baru disajikan di kelas. Seperti halnya butir ketiga di atas kegiatan ini perlu ditindaklanjuti dengan kegiatan belajar berstruktur dan mandiri di luar jam pelajaran.

4) Di luar proses pembelajaran yang berbentuk tatap muka di dalam kelas. Kegiatan ini lebih dikenal dengan proses kajian mandiri. Para peserta diklat baik secara perorangan ataupun kelompok (kecil) melalui tugas berstruktur dan mandiri yang ditugaskan oleh instruktur perlu diberi keleluasaan yang sebesar-besarnya untuk melakukan analisis materi pelajaran dan berkomunikasi dengan berbagai format sumber belajar.

5) Berbagai kegiatan atas dasar inisiatif peserta diklat sendiri baik perorangan maupun dalam bentuk kelompok. Kegiatan ini dapat dilakukan di perpustakaan, laboratorium, ataupun di rumah. Kegiatan ini tidak harus terkait langsung dengan program pembelajaran di kelas. Tujuan utamanya adalah untuk mendorong kebiasaan peserta diklat dalam membaca dan belajar.

6) Lingkungan diklat baik yang ada di dalam maupun di luar diklat dapat dijadikan tempat belajar peserta diklat secara langsung. Pembelajaran di diklat jangan hanya terfokus dengan kegiatan belajar peserta diklat yang dilaksanakan di dalam kelas. Kita dapat memanfaatkan segala fasilitas sumber belajar yang tersedia secara dinamis dan fleksibel.

Modul Supervisi Akademik selain difungsikan sebagai bahan ajar juga sebagai media pembelajaran. Penggunaan media pembelajaran pada tahap orientasi pengajaran akan sangat membantu keefektifan proses pembelajaran dan penyampaian pesan dan isi pelajaran pada saat itu (Wiratmojo dan Sasonohardjo dalam Falahudin, 2014). Ditegaskan oleh Danim dalam Mahnun (2012) bahwa hasil penelitian telah banyak membuktikan efektivitas penggunaan alat bantu atau media dalam proses belajar-mengajar di kelas.

Model/pola pembelajaran merupakan suatu cara yang efektif untuk dapat meningkatkan kualitas pembelajaran (Lewis dalam Warsita, 2014). Model pembelajaran merupakan landasan praktik pembelajaran hasil penurunan teori psikologi pendidikan dan teori belajar yang dirancang berdasarkan analisis terhadap implementasi kurikulum dan implikasinya pada tingkat operasional di kelas (Suprijono, 2009:45).

Proses belajar adalah perubahan pada diri individu dalam aspek pengetahuan, sikap, keterampilan, dan kebiasaan sebagai produk dan interaksinya dengan lingkungan (Winkel dalam Warsihna, 2013; Warsita, 2014). Dengan demikian suatu proses belajar dapat dikatakan berhasil bila di dalam diri individu terbentuk pengetahuan, sikap, keterampilan, atau kebiasaan baru yang secara kualitatif lebih baik dari sebelumnya.

Hilgard dalam Waldopo (2012) menjelaskan bahwa "Learning is the process by which an activity originates or is changed through training procedures (whether in the laboratory or in the environment)." Disini ditekankan bahwa terjadinya perubahan tingkah laku ditempuh melalui sebuah pelatihan baik di laboratorium atau alam sekitarnya. 
Mencermati model pembelajaran yang dilaksanakan pada diklat calon kepala sekolah dengan memanfaatkan modul Supervisi Akademik berfokus kepada model belajar melalui pengalaman (experiential learning) dan model pemecahan masalah (problem solving). Model belajar melalui pengalaman bertujuan untuk melibatkan peserta diklat dalam situasi yang memberi implikasi perubahan perilaku yang sarat nilai dan sikap sosial sedangkan model pemecahan masalah bertujuan untuk mengkaji dan memecahkan masalah melalui interaksi dialogis dalam situasi yang sarat penalaran induktif.

Model belajar melalui pengalaman dan pemecahan masalah yang dilaksanakan pada diklat calon kepala sekolah meliputi: 1) simulasi merupakan peniruan pekerjaan yang berkaitan dengan tugas yang akan menjadi tanggung jawabnya kelak jika sudah menjabat yang menuntut kemampuan tertentu dari peserta diklat sesuai dengan kurikulum yang ditetapkan. 2) Bermain peran bertujuan memberikan kesempatan kepada peserta diklat untuk berlatih menumbuhkan kesadaran dan kepekaan sosial serta sikap positif, selain menemukan alternatif pemecahan masalah. 3) Curah pendapat (brainstorming) bertujuan untuk mencari pemecahan masalah serta digunakan untuk tujuan penyusunan program, prosedur kerja, dan sebagainya. 4) Diskusi kelompok adalah suatu kegiatan yang dihadiri dua orang atau lebih untuk berbagi ide dan pengalaman serta memperluas pengetahuan. 5) Studi kasus digunakan untuk mengembangkan kemampuan/ keterampilan memecahkan masalah. Studi kasus merupakan satu bentuk simulasi untuk mempelajari kasus nyata atau kasus sekarang.

Dalam merencanakan model pembelajaran dengan menggunakan media dan teknologi dapat digunakan model ASSURE. Langkah-langkah yang digunakan (Smaldino, 2011: 112-139) dalam (Achmadi, Suharno \& Suryani,
2014; Giarti, 2012; Jayanti, Putra \& Suryaabadi, 2014; Kurniawati, 2017) yaitu:

a. Tahap pertama: Analyze Learner (Analisis pebelajar)

Penganalisaan pebelajar dilakukan untuk mendapatkan kebutuhan belajar peserta diklat sehingga mereka mampu mendapatkan tingkatan pengetahuan dalam pembelajaran secara maksimal

b. Tahap Kedua: State Standards and Objectives (Merumuskan standard dan tujuan)

Sanjaya (2010: 186) menyatakan tujuan pembelajaran adalah kemampuan (kompetensi) atau keterampilan yang diharapkan dapat dimiliki setelah melakukan proses pembelajaran tertentu. Dalam kurikulum berorientasi pencapaian kompetensi, tujuan pembelajaran itu juga bisa diistilahkan dengan indikator hasil belajar. Artinya, apa hasil yang diperoleh peserta diklat setelah mereka mengikuti proses pembelajaran.

c. Tahap Ketiga: Select Strategies, Technology, Media, and Materials (Memilih strategi, teknologi, media dan materi)

Dalam memilih strategi, teknologi, dan bahan ajar yang perlu diperhatikan adalah strategi harus berpusat pada guru dan peserta diklat dengan mempertimbangkan sumber daya yang ada dan karakteristik peserta diklat, sedangkan bahan ajar yang disampaikan bisa dengan memilih materi yang tersedia, mengubah materi yang tersedia atau merancang materi baru sehingga tujuan pembelajaran dapat tercapai.

d. Tahap keempat: Utilize Technology, Media and Materials (Menggunakan teknologi, media dan bahan ajar)

Perubahan paradigma pembelajaran dari teacher- centered ke studentcentered lebih memungkinkan pebelajar untuk memanfaatkann materi baik secara mandiri atau kelompok 
kecil daripada mendengarkan presentasi instruktur secara klasikal.

e. Tahap Kelima: Require Learner Participation (Mengharuskan

Partisipasi Peserta Didik)

Kaum konstruktivis memandang belajar sebagai proses aktif. Tujuan utama dari pembelajaran adalah adanya partisipasi peserta diklat terhadap materi dan media serta teknologi yang digunakan dalam pembelajaran. Dengan melibatkan peran pebelajar untuk menggunakan terknologi, strategi dan materi akan dapat membantu pebelajar mencapai tujuan belajarnya.

f. Tahap Keenam: Evaluate and Revise (mengevaluasi dan merevisi)

Pada tahap keenam instruktur harus mengevaluasi dan merevisi strategi, teknologi, media dan bahan ajar sebelum digunakan maupun sesudah digunakan. Evaluasi bertujuan untuk menilai sejauh mana tujuan belajar tercapai oleh peserta diklat serta untuk strategi, teknologi, dan media sudah berjalan secara efektif dan membangkitkan minat para peserta diklat atau belum. Sedangkan revisi bertujuan untuk memperbaiki hasil belajar dan merevisi strategi, teknologi, dan media.

Sadiman dkk. (2007) mengemukakan ada 2 (dua) pola pemanfaatan media pembelajaran yang dapat dilakukan yaitu pemanfaatan media dalam situasi kelas (classroom setting) dan pemanfaatan media di luar situasi kelas. Pemanfaatan media di luar situasi kelas meliputi pemanfaatan secara bebas, pemanfaatan media secara terkontrol, dan pemanfaatan media secara perorangan, kelompok atau massal.

Pemanfaatan modul supervisi akademik sebagai bahan ajar dipengaruhi oleh banyak faktor, yaitu: a) fasilitator: Rusman (2012) menyatakan apapun sumber belajar yang diperlukan, syarat utama adalah instruktur dapat menggunakannya dalam proses pembelajaran. Nilai dan manfaat yang diharapkan bukan pada sumber belajarnya, tetapi dampak dari penggunaan sumber belajar bagi kebermaknaan bagi peserta diklatnya. Lebih lanjut Mulyasa (2009) menjelaskan bahwa master trainer dalam sistem pembelajaran modul tugasnya bukan untuk menyampaikan bahan kepada peserta diklat namun mengorganisasi dan mengatur proses pembelajaran, antara lain: (1) menyiapkan situasi pembelajaran yang kondusif, (2) membantu peserta diklat yang mengalami kesulitan di dalam memahami isi modul atau pelaksanaan tugas, dan (3) melaksanakan penelitian terhadap setiap peserta diklat. b) peserta diklat, Pembelajaran dengan sistem modul biasanya terfokus pada seperangkat kompetensi yang harus dikuasai peserta diklat sehingga mampu melakukan aktivitas-aktivitas untuk mencapai tujuantujuan pembelajaran. c) suasana dan lingkungan sekitar diklat: Klausmeier dan Goodwin dalam Anwas (2012) menyatakan salah satu faktor penting dalam mencapai efektifitas belajar adalah dukungan fasilitas untuk belajar, d) latar belakang pendidikan serta e) usia.

\section{PENUTUP}

Berdasarkan hasil penelitian dan pembahasan yang telah diuraikan, maka disimpulkan beberapa hal yang berkaitan dengan kegiatan penelitian:

a. Modul Supervisi Akademik pada diklat calon kepala sekolah telah memenuhi karakteristik yang harus ada pada modul.

b. Strategi pengembangan modul terdiri dari tahap perencanaan; tahap penulisan; tahap review, uji coba dan revisi; serta tahap finalisasi dan pencetakan.

c. Modul Supervisi Akademik digunakan sebagai bahan pembelajaran utama.

d. Sebelum melaksanakan diklat CKS, Master Trainer harus mempersiapkan skenario 
pembelajaran berupa RBPMD dan RP.

e. RBPMD Supervisi Akademik memuat media dan sumber belajar yang bervariasi dan sesuai dengan karakteristik mata diklat.

f. Evaluasi pembelajaran supervisi akademik yang termuat dalam rencana pembelajaran meliputi penilaian terhadap aspek pengetahuan, sikap, dan keterampilan.

g. Strategi pembelajaran yang direncanakan untuk diterapkan meliputi brainstorming dan eksplorasi, diskusi kelompok dan kelas, tanya jawab, ceramah, penugasan individu dan kelompok, presentasi, roleplay serta simulasi.

h. Selesai pembelajaran tatap muka In-1 terdapat tindak lanjut pada saat OJL yaitu peserta diklat menyusun program dan mempraktikkan program supervisi kepada guru junior di sekolah magang sendiri selama 3 bulan.

i. Modul Supervisi Akademik digunakan mulai dari persiapan, pelaksanaan, dan pasca pembelajaran pada tahap in service learning 1 dan on the job learning.

j. Pihak yang terlibat dalam pembelajaran modul yaitu MT, peserta diklat, panitia, dinas dan BKD.

k. Peserta diklat merespon modul Supervisi Akademik dalam aspek tampilan modul, substansi isi, keterbacaan, pedagogis, dan kebermanfaatan

1. Modul Supervisi Akademik digunakan mulai dari persiapan, pelaksanaan, dan pasca pembelajaran pada tahap in service learning 1 dan on the job learning.

m. Faktor-faktor yang mempengaruhi pemanfaatan modul mencakup fasilitator, peserta diklat, suasana dan lingkungan diklat, latar belakang pendidikan, usia serta pengalaman.

Berdasarkan hasil penelitian penulis mengajukan beberapa rekomendasi sebagai berikut:

1. Bagi LPPKS

Penyamaan persepsi tentang definisi, karakteristik, dan prinsip-prinsip, dan cara membelajarkan modul Supervisi Akademik yang digunakan pada diklat CKS perlu dilakukan pada setiap kali pelaksanaan diklat penyegaran master trainer.

2. Bagi Direktorat Pembinaan Tendik Dikdasmen

Perlu dilakukan upaya tindak lanjut berupa diklat penguatan (in service training) khusus tentang supervisi yang ditujukan kepada kepala sekolah dalam jabatan (existing principals). Selain itu harus ada keselarasan antara soal UKKS dengan materi penyelenggaraan diklat.

3. Bagi Peneliti Selanjutnya

Perlunya penelitian lebih lanjut dengan fokus yang sama yaitu pemanfaatan modul supervisi akademik namun dengan kasus yang berbeda, jumlah responden yang lebih banyak dan lokasi penelitian yang lebih diperluas.

4. Bagi PK UPI

Pengembangan bahan ajar diklat sebagai salah satu komponen pengembangan kurikulum pendidikan non formal perlu ditingkatkan dan mendapat perhatian untuk memberikan kontribusi yang berarti dalam upaya meningkatkan kompetensi tenaga kependidikan.

\section{UCAPAN TERIMA KASIH}

Kami berterima kasih kepada pihak kementerian pendidikan dan kebudayaan penyelenggara beasiswa unggulan atas sokongan dana yang diberikan. Terima kasih pula kepada Prof. Dr. Nunuk Suryani beserta jajarannya di LPPKS serta seluruh master trainer, peserta, dan panitia diklat calon kepala sekolah kabupaten Tasikmalaya yang 
secara penting berperan dalam pelaksanaan penelitian ini.

\section{DAFTAR PUSTAKA}

Abdullah, R. (2012). Pembelajaran Berbasis Pemanfaatan Sumber Belajar. Jurnal Ilmiah DIDAKTIKA, Vol. XII, No. 2, Februari 2012, hlm. 216-231.

Achmadi, Suharno, H. \& Suryani, N. (2014). Penerapan Model ASSURE Dengan Menggunakan Media Power Point dalam Pembelajaran Bahasa Inggris sebagai Usaha Peningkatan Motivasi dan Prestasi Belajar Siswa Kelas X MAN Sukoharjo Tahun Pelajaran 2012/2013. Jurnal Teknologi Pendidikan dan Pembelajaran, Vol. 2, No. 1, hlm. 3548.

Ambarita, B., Siburian, P. \& Purba, S. (2014). Development of Academic Supervision Model which Based on Educational Management. International Journal of Sciences: Basic and Applied Research (IJSBAR), Vol. 18, No. 1, pp. 304314.

Anwas, O. M. (2012). Faktor-faktor yang Mempengaruhi Pemanfaatan Media Massa sebagai Media Pembelajaran. Jurnal Teknodik, Vol. XVI, No. 3, September 2012.

Danim, S. (2013). Pedagogi, Andragogi, dan Heutagogi. Bandung: Alfabeta.

Falahudin, I. (2014). Pemanfaatan Media dalam Pembelajaran. Jurnal Lingkar Widyaiswara, Edisi 1, No. 4, hlm. 104-117.

Giarti, Sri. (2012). Penerapan Model Pembelajaran ASSURE untuk Meningkatkan Hasil Belajar IPA Siswa Kelas VI SD Negeri 2 Bengle Kecamatan Wonosegoro - Boyolali. Scholaria, Vol. 2, No. 1, Januari 2012, hlm. 195-215.

Hamalik, O. (1993). Pengembangan Kurikulum dan Pembelajaran: Dasar dan Strategi Pelaksanannya di
Perguruan Tinggi. Cetakan 1. Jakarta: PT Trigenda Karya.

Hasan, S. H. (2014). Evaluasi Kurikulum. Cetakan Ketiga, Desember 2014. Bandung: PT Remaja Rosdakarya.

Hendarman. (2016). Revolusi Kinerja Kepala Sekolah. Cetakan ketiga. Jakarta: PT Indeks.

Iwantoro. (2014). Kompetensi Supervisi Kepala Sekolah Meningkatkan Kinerja Guru dalam Rangka Mencapai Tujuan Pendidikan. Jurnal Ilmu Tarbiyah "At-Tajdid", Vol. 3, No. 2, Juli 2014, hlm. 53-65.

Jayanti, Ni Gst. A. Md. Armita, Md. Putra \& I B. Gd. Suryaabadi. (2014). Pengaruh Penerapan Model pembelajaran ASSURE Berbantuan Media Audiovisual terhadap Hasil Belajar PKn Siswa Kelas V SD Gugus IV Kediri, Tabanan. E-Journal Mimbar PGSD Universitas Pendidikan Ganesha Jurusan PGSD, Vol. 2, No. 1, Tahun 2014.

Kemp, J. E. (1994). Proses Perancangan Pengajaran. Bandung: Penerbit ITB Bandung.

Mahnun, N. (2012). Media Pembelajaran (Kajian terhadap Langkah-Langkah Pemilihan Media dan Implementasnya dalam Pembelajaran). Jurnal Pemikiran Islam, Vol. 37, No. 1, Januari-Juni 2012, hlm. 27-35.

Mintadji. (2015). Implementasi Supervisi Akademik Kepala Sekolah SMP Negeri di Tarakan. Jurnal Kebijakan dan Pengembangan Pendidikan, Vol. 3, No. 1, Januari 2015, hlm. 82-87.

Mulyasa, E. (2002). Kurikulum Berbasis Kompetensi. Bandung: PT Remaja Rosdakarya.

Mulyasa, E. (2008). Menjadi Guru Profesional: Menciptakan

Pembelajaran Kreatif dan Menyenangkan. Bandung: PT Remaja Rosdakarya.

Mulyasa, E. (2009). Menjadi Kepala Sekolah Profesional. Cetakan kesepuluh, Oktober 2009. Bandung: PT Remaja Rosdakarya. 
Mustamin \& Yasin, M. A. M. (2012). The Competence of School Principals: What Kind of Need Competence for School Success?. Journal of Education and Learning, Vol. 6(1), pp. 33-42.

Miles, M. B. \& Huberman, A. M. (1984). Qualitative Data Analysis. Baverly Hills: Sage Publication.

Moleong, Y. L. (2017). Metode Penelitian Kualitatif. Bandung: PT Remaja Rosdakarya.

Nurdin, Syafruddin \& Adriantoni. (2016). Kurikulum dan Pembelajaran. Jakarta: PT RajaGrafindo Persada.

Prawiladilaga, D. S. \& Siregar, E, ed. (2004). Mozaik Teknologi Pendidikan. Jakarta: Prenada Media.

Purnama, E. K. (2012). Intensitas Pemanfaatan Sumber Belajar dan Sikap Mahasiswa pada Profesi Guru terhadap Prestasi Belajar Profesi Keguruan. Jurnal Teknodik, Vol. XVI, No. 2, Juni 2012.

Purwanto, Rahadi, A. \& Lasmono, S. (2007). Pengembangan Modul. Jakarta: Pusat Teknologi Informasi dan Komunikasi Pendidikan, Depdiknas.

Rahman, M. H. (2015). Learning Assessment in a Self Learning Material. International Journal on New Trends in Education and Their Implications, July 2015, Volume: 6, Issue: 3, Article: 10, pp. 95-101.

Rifaldi, M. A. \& Roesminingsih, E. (2014). Pengaruh Supervisi Kepala Sekolah dan Motivasi Kerja Guru terhadap Kepuasan Kerja Guru di SMK ADB INVEST Se-Kota Surabaya. Jurnal Inspirasi Manajemen Pendidikan, Vol. 4, No. 4, April 2014, hlm. 122-133.

Robinson, J. W. Jr. \& Crittenden, W. B. (1972). Learning Modules: A Concept for Extension Educators?. Journal of Extension: Winter 1972, pp. 35-44.

Rusman. (2012). Manajemen Kurikulum. Jakarta:PT Raja Grafindo Persada.
Rusman. (2017). Belajar \& Pembelajaran Berorientasi Standar Proses Pendidikan. Jakarta: Kencana

Sadiman, A. S. dkk. (2007). Media Pendidikan: Pengertian, Pengembangan, dan Pemanfaatannya. Jakarta: PT RajaGrafindo Persada.

Sanjaya, W. (2005). Pembelajaran dalam Implementasi Kurikulum Berbasis Kompetensi. Jakarta: Kencana.

Soemantrie, H. (2010). "Kompetensi" Sebagai Landasan Konseptual Kebijakan Kurikulum Sekolah di Indonesia. Jurnal Pendidikan dan Kebudayaan, Vol. 16. No. 6, Nopember 2010. hlm. 684-698. Pusat Kurikulum. Badan Penelitian dan Pengembangan Nasional. Kemendiknas.

Sukmadinata, N. S. \& Syaodih, E. (2012). Kurikulum dan Pembelajaran Kompetensi. Cetakan kesatu, Juli 2012. Bandung: PT Refika Aditama.

Sukmadinata, N. S. (2017). Metode Penelitian Pendidikan. Cetakan Keduabelas, Oktober 2017. Bandung: PT Remaja Rosdakarya.

Suryantini. (2016). Peningkatan Kompetensi Supervisi Kepala Sekolah melalui Supervisi Kelompok di Sekolah Dasar. Jurnal Managemen Pendidikan, Vol. 11, No. 2, Januari 2016, hlm. 9-17.

Suwartini, E. A. (2017). Supervisi Akademik Kepala Sekolah, Profesionalisme Guru dan Mutu Pendidikan. Jurnal Administrasi Pendidikan, Vol. XXIV, No. 2, Oktober 2017, hlm. 62-70.

Syafmawati, I. (2013). Persepsi Guru tentang Kompetensi Supervisi Kepala Sekolah SD Negeri Kecamatan Padang Timur Kota Padang. Bahana Manajemen Pendidikan: Jurnal Administrasi Pendidikan, Vol. 1, No. 1, Oktober 2013, hlm. 93-100.

S., Tatang (2016). Supervisi Pendidikan. Cetakan kesatu, Januari 2016. Bandung: CV Pustaka Setia. 
Wahyudin, Dinn. (2014). Manajemen Kurikulum. Bandung: PT Remaja Rosdakarya.

Waldopo. (2012). Pembelajaran Berbasis Masalah, Sebuah Strategi Pembelajaran untuk Menyiapkan Kemandirian Peserta Didik. Jurnal Teknodik, Vol. XVI, No. 3, September 2012.

Warsihna, J. (2013). Pemanfaatan TIK untuk Pendidikan (E-Learning) di SMP. Jurnal Teknodik, Vol. 17, No. 1, Maret 2013.

Warsita, B. (2014). Pola Kegiatan Pembelajaran dalam Pendidikan Jarak Jauh. Jurnal Teknodik, Vol. 18, No. 1, April 2014.

Yin, R. K. (2015). Studi Kasus: Desain \& Metode. Cetakan Keempatbelas, Agustus 2015. Jakarta: PT RajaGrafindo Persada.

Peraturan Menteri Pendidikan Nasional Nomor 13 Tahun 2007 tentang Standar Kompetensi Kepala Sekolah/Madrasah

Peraturan Menteri Pendidikan dan Kebudayaan Nomor 6 Tahun 2018 tentang Penugasan Guru Sebagai Kepala Sekolah

Any, J. I. (2011). Pemanfaatan SumberSumber Belajar dalam Proses Pembelajaran di SMP Negeri 2 Lebaksiu Kabupaten Tegal. (Skripsi). Jurusan Kurikulum dan Teknologi Pendidikan Fakultas Ilmu Pendidikan Universitas Negeri Semarang.
Direktorat Jenderal Peningkatan Mutu Pendidik dan Tenaga Kependidikan. (2007). Supervisi Akademik dalam Peningkatan Profesionalisme Guru. Jakarta: Depdiknas.

Jawadha, A. (2015). Implementasi Penggunaan Modul untuk Meningkatkan Keaktifan dan Prestasi Belajar pada Pembelajaran Pemeliharaan Mesin Kendaraan Ringan Kelas XI Otomotif SMK Ma'arif Wates. (Skripsi). Program Studi Pendidikan Teknik Otomotif, Fakultas Teknik Universitas Negeri Yogyakarta.

Kurniawati. (2017). Penerapan LangkahLangkah Model ASSURE dalam Pemilihan Media Mata Pelajaran IPA oleh Guru SD Negeri Kelas Rendah Se-Kecamatan Seyegan. (Skripsi). Program Studi Teknologi Pendidikan Jurusan Kurikulum dan Teknologi Pendidikan Fakultas Ilmu Pendidikan Universitas Negeri Yogyakarta.

Lilawati, J. (2017). Analisis Pemanfaatan Sumber Belajar dalam Proses Pembelajaran. Prosiding Seminar Nasional Tahunan Fakultas Ilmu Sosial Universitas Negeri Medan Tahun 2017, hlm. 106-109.

Website https://kbbi.web.id/analisis diakses tanggal 26 Januari 2018

$\underline{\text { Website }}$

http://id.wikipedia.org/pembelajaran diakses tanggal 26 Januari 2018 